\title{
DONGENG ORIGINAL NUSANTARA (DANA) BASED ON STORY BASED LEARNING (SBL) TO IMPROVE THE ABILITY OF TEACHER TEACHERS IN SURAKARTA
}

Fadhil Purnama Adi, Hadi Mulyono, Idam Ragil Widianto Atmojo, Roy Ardiansyah

Universitas Sebelas Maret

fadhil@staff.uns.ac.id

\section{Article History}

accepted 09/07/2018

approved 01/08/2018

published 17/09/2018

Keywords

Dongeng, Learning, Story

Based Learning

\section{Abstract}

The purpose of this service is to improve the ability of elementary school teachers in realizing enjoyable learning through the development of archipelago dongeng material. The subject of this service is an elementary school teacher in the city of Surakarta. The method used in this service begins the Workshop, Practices, and Implementation. In conducting this training, subjects were asked to work on tests related to the development of fairy tale material. Analysis of the data used is pre-test and post-test. The results of this activity are an increase in the knowledge and understanding of teachers about the development of the archipelago fairy tale teaching materials.

Social, Humanities, and Education Studies (SHEs): Conference Series https://jurnal.uns.ac.id/shes 


\section{PENDAHULUAN}

Pendidikan Karakter merupakan orientasi pendidikan Indonesia saat ini, terlebih dengan adanya penerapan kebijakan Kurikulum 2013 yang menekankan pada pentingnya pembentukan dan penguatan karakter. Urgensi karakter menurut Lickona Lickona (1992) mengemukakan beberapa alasan tentang perlunya pendidikan karakter bagi peserta didik, yaitu: (a) karakter merupakan hal yang sangat esesnsial dalam berbangsa dan bernegara; (b) karakter berperan sebagai kendali dan kekuatan sehingga bangsa ini tidak mudah terombang ambing; dan (c) karakter tidak datang dengan sendirinya, tetapi harus dibangun dan dibentuk untuk menjadi bangsa yang bermartabat. Pembelajaran yang ada saat ini harus menekankan pada bagaiamana cara atau metode yang digunakan oleh guru mengarah kepada pembentukan karakter siswa. Salah satu metode yang dapat digunakan dalam membentuk karakter adalah Dongeng.

Dongeng merupakan kisah yang disampaikan dengan cara bercerita. Menurut (Nurgiantoro, 2005:198) pengertian dongeng adalah cerita yang tidak benar-benar terjadi dan dalam banyak hal sering tidak masuk akal. Dongeng biasanya disampaikan dan dibacakan oleh guru TK, SD, mulai kelas 1-3 SD, antara umur 5-10 tahun. Selain itu dongeng juga diceritakan para orang tua disaat menemani anak-anaknya menjelang tidur. Anak-anak sangat suka ketika guru dan orang tua mereka mendongeng, apalagi dongeng pengantar tidur. Imajinasi seorang anak berkembang ketika mendengarkan sebuah dongeng. Anak-anak membayangkan tokoh, tempat, dan peristiwa yang dikisahkan. Hal ini cukup efektif, karena anak mampu menyerap dengan mudah gambaran tentang baik dan buruknya sesuatu hal melalui isi sebuah dongeng.

Kisah dongeng membawa pendengarnya terhanyut ke dalam dunia fantasi. Imajinasi dan fantasi adalah sebuah proses kejiwaan yang sangat penting. Rasa ingin tahu ini sangat penting bagi perkembangan intelektual anak. Penyampaian pesan moral dapat dilakukan melalui nilai-nilai positif melalui isi dongeng, biasanya lebih didengarkan anak. Karena anak senang medengarkannya, maka secara otomatis pesan-pesan yang kita selipkan kemudian didengarkan anak dengan senang hati. Namun terdapat beberapa hal yang harus dilakukan oleh guru agar siswa tetap memiliki ketertarikan terhadap dongeng yang disampaikan. Menurut Lustantini (1998: 16) penyebab ketertarikan audience pada dongeng tidak terlepas dari empat unsur penting dongeng yaitu:(1) Alur, (2) Tokoh, (3) Latar, (4) Tema. Oleh karenanya guru harus memiliki kemampuan untuk mengakomodir dongeng diintegrasikan di dalam materi pembelajaran.

Dongeng dapat dinikmati beberapa kalangan, mulai dari anak-anak, remaja, dan orang dewasa. Pesan moral yang disampaikan dalam dongeng biasanya merupakan petunjuk bertingkah laku di masyarakat, ajaran baik dan buruk, tidak boleh ombong dan durhaka, bermakna dan penuh surf tauladan, dan berbagai kegembiraan, kebahagiaan, kesedihan, kemalangan, dan derita. Melalui pesan moral juga dapat melatih perasan emosi, menghayati berbagai lakon dikehidupan manusia dan dapat berperan dalam proses pembentukan watak seorang anak. (Sudarmadji, dkk. 1992:4).

Dongeng merupakan suatu kisah yang diangkat dari "cerita tidak nyata atau pemikiran fiktif' menjadi suatu alur perjalanan hidup. Di dalam dongeng terkandung pesan moral yang mengajarkan makna hidup dan cara berinteraksi dengan makhluk lainnya. Dongeng juga merupakan dunia hayalan dan imajinasi dari pemikiran seseorang yang kemudian diceritakan secara turun-temurun dari generasi ke generasi. Dongeng memiliki beragam jenis, antara lain mitos, legenda, sage dan fable. Dongeng dapat merangsang siswa untuk kreatif karena yang dijangkau dari metode ini adalah alam imajinasi siswa sehingga memberikan sebuah pembelajaran yang bermakna bagi siswa. Siswa lebih mudah menerima apa yang disampaiakn guru ketika guru 
menggunakan metode ini. Serta siswa kan terhindar dari rasa jenuh dan bosan saat mengikuti pembelajaran.

Dongeng yang diberikan kepada siswa sebaiknya adalah dongeng yang berakar dari kearifan lokal yang dimiliki oleh Indonesia atau biasa disebut sebagai dongeng Asli Nusantara. Bahasa yang lebih sederhana adalah menggunakan cerita rakyat sebagai basic dari pembauatan materi ajar dongeng yang digunakan. Cerita rakyat merupakan salah satu dari sekian banyak ragam tradisi lisan di Indonesia. Cerita rakyat bagi masyarakat Indonesia berperan penting bagi kehidupannya. Melalui cerita rakyat, masyarakat merasa hidup aman, tenteram dan damai karena fungsi salah satu cerita rakyat itu adalah menjadikan mereka merasa bersaudara, karena mereka yakin bahwa mereka berasal dari nenek moyang yang sama.

Cerita rakyat sangat besar pengaruhnya terhadap masyarakatnya, karena mampu menjadi pedoman hidup bagi masyarakatnya, itu juga berlaku pada cerita rakyat masyarakat di Indonesia dan cerita rakyat merupakan tradisi lisan, Indonesia adalah negara yang kaya akan nilai - nilai budaya dan kearifan lokal yang telah diwariskan secara turun temurun. Tradisi lisan mengungkapkan kejadian atau peristiwa yang mengandung nilai moral, keagamaan, adat istiadat, fantasi, peribahasa, nyanyian dan mantra. Cerita rakyat yang sarat nilai - nilai moral dan kearifan lokal yang bisa menjadi sarana komunikasi untuk mengajarkan nilai- nilai tentang kehidupan kepada anak-anak.

Kolabarasi antara Dongeng dengan memanfaatkan cerita rakyat sebagai akar atau ide cerita dapat disebut sebagai Dongeng Asli Nusantara. Dengan memanfaatkan metode mempengarahui penerimaan siswa dalam belajar terlebih Dongeng Asli Nusantara ini di basiskan dengan Story Based Learning.

Dongeng termasuk salah satu metode di dalam pembelajaran yang menjadikan pembelajaran menarik karena adannya interaksi antara siswa dengan guru dan juga dongeng dapat membawa siswa seakan-akan larut dal cerita yang disampaikan oleh karenanya pada hakikatnya dongeng sebagai teknik dalam pemebalajran menempati posisi yang cukup penting sebagai salah satu komponen sistem pembelajaran. Pengembangan materi dongeng berbasisis Story Based Learning yang didukung kemampuan guru dalam mengeksplorasi dongeng memberikan dampak yang signifikan terhadap kualitas dari pembelajaran.

Optimalisasi penggunaan dongeng berbasis SBL yang disertai dengan pengembangan materinya berbahan dasar cerita rakyat dalam kegiatan pembelajaran yang diyakini dapat meningkatkan mutu pendidikan. Salah satu manfaat dengan menggunakan dongengn berbasis $\mathrm{SBL}$ adalah pesan yang disampaikan oleh pendidik dapat lebih mudah dimengerti atau dipahami oleh peserta didik serta secara psikologis siswa tidak merasa terbebani. Inilah peran yang harus diberikan guru dalam pembelajaran, Doyle sebagaimana dikutip oleh Danim (2002:1) mengemukakan dua peran guru dalam pembelajaran yaitu menentukan keteraturan (estabilishing order) dan memfasilitasi proses belajar (facilitating learning), yang dimaksud keteraturan disini mencakup hal-hal yang terkait langsung atau tidak langsung dengan proses pembelajaran, seperti : tata letak tempat duduk, disiplin peserta didik di kelas, interaksi peserta didik dengan sesamanya, interaksi peserta didik dengan guru, jam masuk dan keluar untuk sesi mata pelajaran, pengelolaan sumber belajar, pengelolaan bahan belajar, prosedur dan sistem yang mendukung proses pembelajaran, lingkungan belajar dan lain-lain.

Workshop penyusunan materi Dongeng Berbasis SBL dengan mengedepankan cerita rakyat sebagai bahan dasar pembuatan materi dapat menginternalisasikan nilainilai luhu budaya bangsa dan tentunya membuata suasana pebelajaran yang menarik, tidak monoton, tetapi tidak kehilangan esensi dari tujuan pembelajaran. Dongeng Berbasis SBL dapat menunjang kreatifitas guru dan siswa serta dapat mengemas 
pembelajaran sesuai dengan Kurikulum 2013. Pemanfaatan Cerita Rakyat Asli Nusantara dalam pembuatan materi Dongeng berbasis SBL menjadi MATERI ajar membutuhkan kreatifitas dan keinginan para pendidik untuk mencari, menemukan dan mengembangkannya. Disinilah dibutuhkan kreatifitas guru dan siswa untuk menciptakan materi dongeng berbasis SBL yang lebih kreatif dan inovatif namun tidak kehilangan esensi dari konsep kurikulum yang ada. Materi Dongeng yang disusun dapat digunakan untuk membantu siswa dalam memahami materi pelajaran tidaklah harus yang panjang atau luas, tetapi cukup materi dogeng yang digunakan sesuai dengan tujuan dan karakteristik pembelajaran serta tetap menjaga esensi pembelajaran.

Cerita Rakyat Asli Nusantara yang selama ini di dideskreditkan karena dianggap ketinggalan zaman, tidak up to date, dan sulit untuk diintegrasikan di dalam pelaksanaan pembelajaran teratasi dengan menggunakan penyusunan materi yang sesuai dengan cerita rakyat yang ada, serta dapat menginternalisasikan nilai-nilai luhur budaya di dalam pelaksanaan pembelajaran. Karena pada hakikatnya Cerita Rakyat merupakan warisan yang diberikan secara turun-temurun, sebagaimana disampaikan oleh Suripan Sadi Hutomo (1991: 4) Dahulu, cerita rakyat diwariskan secara turunmenurun dari satu generasi ke generasi berikutnya secara lisan.

Berdasarkan hasil observasi yang dilakukan pada tanggal 10 Januari s.d. 14 Februari 2018 pada 2 orang kepala sekolah (SD Negeri Dukuhan Kerten dan SD N Purwotomo diperoleh hasil bahwa pengetahuan dan kemampuan guru untuk membuat materi ajar dengan menggunakan materi dongeng nusantara masih terhitung rendah, terutama kontek Kurikulum Tematik masih rendah. Dari total guru yang ada di kedua SD mitra sebanyak 35 orang, hanya 2 orang guru atau sekitar $(5,71 \%)$ yang sudah memanfaatkan cerita rakyat atau dongeng dalam arti luas sebagai materi ajar dalam pembelajaran tematik, 2 orang atau sekitar $(5,71 \%)$ guru telah sedikit bercerita tetapi belum kontekstual dalam proses pembelajarannya, namun sisanya sekitar 31 guru belum menggunakan dongeng sebagai materi ataupun metode di dalam pembelajarananya.

Berdasarkan hasil wawancara dengan kepala sekolah, diperoleh hasil bahwa guru-guru mengalami kesulitan untuk menyusun dongenng yang sesuai dengan materi ajar dalm konteks pembelajaran Tematik. Hal ini dikarenakan guru belum mengetahui dan memahami konsep dasar tentang dongeng.

Peran metode atau dapat dikatakan materi dongeng berbasis story based learning adalah untuk melancarkan kegiatan pembelajaran dan mewujudkan pemebaljaran yang bermakna yang mampu untuk mengimnternalisasikan karakter di dalam pelaksanaan pembelajaran, sehingga dibutuhkan workshop yang dapat membantu mempermudah guru untuk memberikan pembelajaran yang inovatif disertai dengan kemasan pembelajaran yang menyenangkan dan menghibur namun tetap tidak kehilangan esensi dari materi ajar. Berdasarkan hasil observasi pendahuluan yang dilakukan pada beberapa SD mitra tersebut diperoleh hasil bahwa kemampuan guru untuk menyusun materi ajar dongeng menjadi materi ajar yang sesuai dengan konten masalah dari pembelajaran untuk dijadikan materi dongeng asli nusantara berbasis Story based learning masih rendah sehingga sangat mendesak dilakukan pemberian informasi dan pelatihan pada guru-guru tersebut.

\section{METODE}

Subjek Subjek dalam pengabdian ini terdiri guru-guru sekolah dasar yang ada di wilayah administrasi kota Surakarta. Metode yang digunakan dalam pelatihan ini Workshop, Praktik, dan Implementasi. Teknik pengumpulan data menggunakan teknik tes. Teknik analisis yang digunakan menggunakan pre test dan post test. 


\section{HASIL DAN PEMBAHASAN}

Berdasarkan hasil pre test yang dilakukan sebelum pelaksanaan kegiatan pengabdian menunjukkan bahwa guru-guru sekolah dasar di Surakarta yang terlibat sebagai peserta dalam kegiatan pengabdian dengan jumlah 50 guru yang terdiri dari lima sekolah dasar di kota Surakarta menunjukkan bahwa kemampuan guru dalam mengembangkan materi ajar dongeng berbasis story based learning (sbl) masih rendah. Hal ini ditunjukkan dari data yang menyatakan bahwa masih terdapat 42 guru atau sebesar $84 \%$ belum tuntas dalam mengerjakan soal pre test terkait dengan pengembangan materi dongeng di dalam pelaksanaan pembelajaran, atau hanya sekitar 8 guru (16\%) yang berhasil lulus. Guru yang berhasil lulus dalam pre test di dominasi oleh guru-guru yang mengajar di kelas rendah, sedangkan guru-guru yang mengajar di kelas atas terlihat kesulitan karena terbiasa dengan penyampaian materi yang ketat sesuai dengan konten dari pembelajaran. Setelah dilaksanakan workshop tentang pengembangan materi ajar berbasis dongeng nusantara kemampuan guru dalam mengembangkan materi ajar dongeng berbasis story based learning (sbl) meningkat dengan tingkat ketercapaian ketuntasan mencapai $76 \%$ atau sekitar 38 guru berhasil lulus dan sekitar 12 guru yang belum berhasil lulus. Hal ini menunjukkan terjadinya peningkatan sekitar $60 \%$ dari pre test ke post test yakni dari 8 guru menjadi 38 guru atau sekitar 30 guru. Secara grafis dapat dilihat dalam grafik 1.1 berikut:

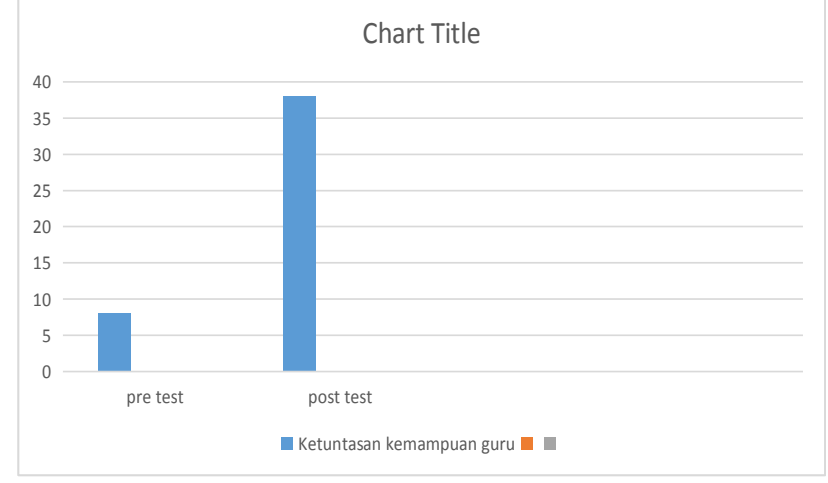

\section{Gambar 1.1 Grafik Hasil perbandingan pre test dan post test kemampuan guru SD}

Berdasarkan hasil pre test dan post test yang telah dilakukan ditemukan fakta bahwa pelatihan yang dilakukan memberikan dampak yang signifikan terhadap kompetensi guru dalam bidang profesionalisme kinerja. Pelatihan yang diberikan tentang pengembangan materi dongeng berbasis story based learning memberikan dampak yang signifikan terhadap kemampuan guru dalam hal pengembangan materi dongeng. Kegiatan workshop atau pelatihan dengan mendatangkan narasumber ahli yang merupakan pakar di bidang tersebut secara tidak langsung sudah memberikan dampak yang positif melalui proses komunikasi yang baik. Sebagaimana dijelaskan dalam Rosmawaty (2010) bahwa komunikasi kelompok adalah komunikasi dalam kelompok kecil orang, dengan tujuan antara lain untuk berbagi informasi, membantu mengembangkan gagasan bahkan membantu untuk memecahkan masalah, baik secara formal maupun tidak formal. Workshop yang dilaksanakan oleh tim berusaha untuk membantu guru dalam menyelesaikan masalah yang dihadapi terlebih di dalam pelaksanaan era disrupsi, sehingga dengan adanya pelatihan ini baik dilaksanakan secara formal ataupun informal akan membantu menyelesaikan permasalahan yang dihadapi oleh guru dalam hal pengembangan materi dongeng 


\section{SIMPULAN}

Berdasarkan dari hasil kegiatan pelatihan atau workshop dapat disimpulkan bahwa dengan pelaksanaan workshop tentang pengembangan materi dongeng nusantara dalam pelaksanaan pembelajaran dapat meningkatkan kemampuan guru dalam mengembangkan materi dongeng yang berbasis pada story based learning yang akan digunakan dalam pelaksanaan pembelajaran.Simpulan ini didapatkan dari hasil analisis pre test dan post test yang dilakukan ketika pelaksanaan kegiatan.

\section{DAFTAR PUSTAKA}

Danim, Sudarwan. (2002). Pengertian Guru Dalam Pendidikan.

Hutomo, Suripan. (1991). Mutiara Yang Terlupakan Pengantara Studi Sastra Lisan. Komisariat Jawa Timur: Hikpunan Sejarah Sastra Indonesia

Lickona, Thomas. (1992). Educating For Character, How Our Schools Can Teach Respect and Responsibility, Bantam Books, New York.

Nurgiyantoro, B. (2005) Sastra Anak (Pengantar Pemahaman Dunia Anak).Yogyakarta: Gadjah Mada University Press.

Rosmawanty HP. (2010). Mengenal IImu Komunikasi. Widya Padjadjaran

Septiningsih,Lustantini.(1998). Komponen-komponen Dongeng. Yogyakarta: IKIP. 